\title{
Innate differences in consumption and utilization of food by the fast- and slow-growing larvae of cabbage looper, Trichoplusia ni (Hübner) (Lep., Noctuidae)
}

\author{
Bv H. C. Sharma and D. M. Norris
}

\begin{abstract}
Consumption and utilization of soybean leaves by the fast versus slow-growing larvac of the cabbage looper, Trichoplusia $n i$ were studied under laboratory conditions. Fast-growing larvae consumed more food/unit of body mass, and gained weight 10 times faster than the slow-growing larvac. Slowgrowing larvae were less efficient in consumption and utilization of food, and the differences in indices of food utilization were greater between the fast-and slow-growing larvac on the relatively resistant soybean cultivar, "PI 227687" than on the stsceptible cultivar, "Davis". Implications of differences in growth rates and food utilization by the fast- and slow-growing larvace on resistant and susceptible cultivars are discussed in relation to evolution of new biotypes and host-plant resistance.
\end{abstract}

\section{Introduction}

Insect populations are genetically diverse, and this increases their capability for survival and reproduction. The genetic variation quite often is not expressed phenotypically, but is evident in terms of adaptation to different host-plants, developmental rates, resistance to insecticides or tolerance to other population suppression factors. Some variation is density dependent and results in selection for an array of traits within a population, which may reduce competition between individuals of the same species (PRICE 1976).

A small proportion of natural and laboratory populations of the cabbage looper, Trichoplusia $n i$ have a slow rate of growth (TIGNOR and FinTON 1986; SMH.owirz and

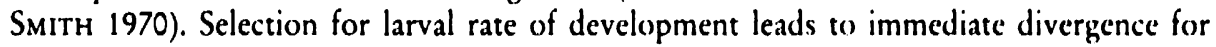
fast- and slow-growing larvae in Cnephasia jactatana (Walk.) (OCHink;-ODero 1990). Fast- or slow-growth of the larvae is controlled by genes regulating the release of prothoracotropic hormone in Sarcophaga argyrostoma R.-D). (BROADL.EY and SAUNDFrs 1986).

The present studies were carried out to determine whether the slow growth rate of $T . n i$ larvae is due to innate differences in consumption and utilization of food. We also examined the effects of an insect-resistant ("P1 227687") and a susceptible ("Davis"), soybean cultivar on the growth of fast- and slow-growing larvac.

\section{Materials and methods}

\subsection{Insects}

Larvae of T. ni were reared on a pinto bean-based artificial diet (SHOREY and Hat.E 1965) under laboratory conditions $\left(25 \pm 1{ }^{\circ} \mathrm{C}\right.$ and $65 \pm 5 \%$ relative humidity). Larval development was monitored in the rearing cups $(100 \mathrm{ml})$, and newly molted third-instar larvae were used for studying the consumption and utilization of food. Fast-growing larvae molted into third instar in about 10 days after egg laying while the slow-growing larvae molted into third-instar in about 18 days. 


\subsection{Plants}

Plants of "PI 227687" and "Davis" soybeans were grown in the greenhouse at the U. S. Dairy Forage Research Center, University of Wisconsin, Madison. Seeds of "PI 227687" and "Davis" were treated with thiram, and germinated in sterilized moistened vermiculite in a $27 \times 27 \times 7 \mathrm{~cm}$ plastic tray kept inside a Percival incubator at $27 \pm 1^{\circ} \mathrm{C}$ and $16 \mathrm{~h}$ photophase. Seedlings at cotyledon opening were transplanted into $20 \mathrm{~cm}$ diameter earthen pots containing a sterilized mixture of soil, sand and vermiculite (2:2:1). Plants were watered daily, and kept under $16 \mathrm{~h}$ photophase using Metalarc ${ }^{\star 2}$ highintensity (1000 Watt) lights. Total light intensity gave 28-36 moles of photon flux. Plants were fertilized at 15-day intervals with Miracle Gro ${ }^{\otimes}(11 \mathrm{~g} / 2.781$ water) (Sterns' Nursery Inc., Geneva, N.Y.), and sprayed with $2.5 \%$ safer ( $50.5 \%$ potassium salts of fatty acids) (Agro. Chem. Inc., Lyons Valley Road, Jamul, Ca.) to control white flies and thrips.

\subsection{Consumption and utilization of food}

Consumption and utilization of fully expanded soybean leaves were studied on trifoliatc number 8 at V10 stage of development (FeHr et al. 1971). A freshly detached leaf was weighed on a Mettler balance and placed in a $9 \mathrm{~cm}$ diameter, $5 \mathrm{~cm}$ deep plastic cup. The cups were covered with a lid having a $9 \mathrm{~cm}$ diameter filter paper moistened with $2 \mathrm{ml}$ water. There were 10 replications for each cultivar and category of larvae. Four-hour-starved pre-weighed larvae were confined with the leaves for two days. The cups were kept in a $27 \times 27 \times 7 \mathrm{~cm}$ plastic tray, which was covered with a similar inverted tray. Five leaves of each cultivar were similarly placed in plastic cups, but without larvac, to record the natural loss of mass in the leaves. The cups were placed in an incubator at $28 \pm 1{ }^{\circ} \mathrm{C}$. At the end of the feeding period, the uneaten leaves, feaces, and larvae were separated, and placed in a drying oven at $80 \pm 2^{\circ} \mathrm{C}$ for $24 \mathrm{~h}$, and then the dry mass was recorded. Larvae were killed with benzene before drying. At the beginning of experiment, 10 larvae were individually weighed, and then dried in the oven to compute an initial mean dry mass of the larvae. Various indices on consumption and utilization of food were calculated on a dry mass basis as described by Wal.DBauer (1968). Significance of difference between treatment means was determined by using paired t-test. Correlation coefficients between different indices of food utilization were also computed.

\section{Results}

There were significant differences $(P<0.05)$ in consumption and utilization of food by the fast- and slow-growing larvae of the cabbage looper, T. ni (table 1). Dry mass of the slowgrowing larvae at the start of the experiment was much higher than that of the fast growing larvae. Fast-growing larvae consumed more food per unit of body mass $(\mathrm{CI})$ compared with the slow-growing larvae. Differences in consumption index (CI) between the fastand slow-growing larvae were greater on the relatively insect resistant cultivar, "PI 227687" (CI 3.3 for fast-versus 0.6 for the slow-growing larvae) than on "Davis" (CI 2.8 for fast-versus 1.0 for the slow-growing larvae).

Table 1. Consumption of food by the fast- and slow-growing larvae of $T . \mathrm{ni}$

\begin{tabular}{|llrrrrr|}
\hline Cultivar & Type of larvae & $\begin{array}{c}\text { Initial wt. of } \\
\text { larva (mg) }\end{array}$ & $\begin{array}{c}\text { Mass of larva } \\
\text { after the feeding } \\
\text { period (mg) }\end{array}$ & $\begin{array}{c}\text { Mass of food } \\
\text { ingested (mg) }\end{array}$ & $\begin{array}{c}\text { Mass of feces } \\
\text { produced (mg) }\end{array}$ & $\begin{array}{c}\text { Consumption } \\
\text { index (CI) }\end{array}$ \\
\hline Pl 227687 & Fast-growing & $2.9 \pm 0.2^{\mathrm{a}}$ & $11.6 \pm 1.6^{\mathrm{a}}$ & $47.4 \pm 9.9^{\mathrm{a}}$ & $11.8 \pm 0.6^{\mathrm{a}}$ & $3.3 \pm 0.5^{\mathrm{a}}$ \\
& $\begin{array}{l}\text { Slow- } \\
\text { growing }\end{array}$ & $18.0 \pm 0.4^{\mathrm{b}}$ & $20.0 \pm 0.4^{\mathrm{b}}$ & $24.3 \pm 1.9^{\mathrm{b}}$ & $15.3 \pm 1.5^{\mathrm{a}}$ & $0.6 \pm 0.01^{\mathrm{b}}$ \\
'Davis' & $\begin{array}{l}\text { Fast-growing } \\
\text { Slow- }\end{array}$ & $3.6 \pm 0.4^{\mathrm{a}}$ & $13.4 \pm 1.1^{\mathrm{a}}$ & $48.0 \pm 7.1^{\mathrm{a}}$ & $19.7 \pm 2.6^{\mathrm{a}}$ & $2.8 \pm 0.2^{\mathrm{a}}$ \\
& $17.4 \pm 1.2^{\mathrm{b}}$ & $20.6 \pm 1.8^{\mathrm{b}}$ & $41.1 \pm 2.8^{\mathrm{a}}$ & $28.0 \pm 1.8^{\mathrm{a}}$ & $1.0 \pm 0.1^{\mathrm{b}}$ \\
& $\begin{array}{l}\text { growing } \\
\text { Figures followed by the same ietter in a cultivar for fast- and slow-growing larvae are not } \\
\text { significantly different at } P<0.05 .\end{array}$
\end{tabular}


Differences in growth rates between fast- and slow-growing larvie were significant $(P<0.05)$ (table 2). Fast-growing larvae grew about 10 times faster than the slow-growing larvae. Differences in growth rates (GR) were also reflected in the efficiency of conversion of ingested $(E C I)$ and digested (ECD) food into body matter. Slow-growing larvae were significantly less efficient compared with fast-growing larvae in $\mathrm{ECl}$ (8.5 to $9.3 \%$ versus 20.9 to $21.3 \%)$ and $\mathrm{AD}(29.3$ to $37.3 \%$ versus 58.3 to $71.3 \%)$. Differences in $\mathrm{ECD})$ between fast- and slow-growing larvae were significant $(P<0.05)$ only on "PI 2.27687".

Table 2. Indices of food utilization by the fast-and slow-growing larvac of $T$. ni

\begin{tabular}{|c|c|c|c|c|c|}
\hline Cultivar & Type of larvace & Growth rate (GR) & $\begin{array}{l}\text { Pefficiency of } \\
\text { conversion of in- } \\
\text { gested fioded (I:C }(1 \%)\end{array}$ & $\begin{array}{l}\text { Approximatc } \\
\text { digcstatility } \\
\text { (AI)"io) }\end{array}$ & $\begin{array}{l}\text { Fifficiency of con- } \\
\text { version of digested } \\
\text { torod (l. (II)" }\end{array}$ \\
\hline \multirow[t]{2}{*}{ 'PI 227687' } & Fast-growing & $0.572 \pm 0.042^{\lambda}$ & $22.8 \pm 4.5^{1}$ & $71.3 \pm 4.0^{4}$ & $31.9 \pm 8.8^{4}$ \\
\hline & Slow-growing & $0.052 \pm 0.002^{\prime \prime}$ & $8.5 \pm 1.0^{11}$ & $37.3 \pm 1.5^{11}$ & $22.5 \pm 1.9^{11}$ \\
\hline \multirow[t]{2}{*}{ 'Davis' } & Fast-growing & $0.576 \pm 0.020^{A}$ & $21.3 \pm 1.7^{\lambda}$ & $58.3 \pm 0.9^{4}$ & $37.1 \pm 3.4^{4}$ \\
\hline & Slow-growing & $0.083 \pm 0.022^{b /}$ & $9.3 \pm 2.0^{\prime}$ & $29.3 \pm 2.5^{5}$ & $32.6 \pm 6.1^{4}$ \\
\hline
\end{tabular}

Correlation coefficients between $\mathrm{CI}$ versus (;R, ECCI and I:CD) were negative for the larvae fed on "PI 227687", and positive for the larvae fed on "l)avis" (except CI versus (iR, $\mathrm{ECI}$ and ECD for the slow-growing larvac) (table 3). Correlation coefficient between $\mathrm{CI}$ versus $A D$ was significant $(P<0.05)$ and positive for fast-growing larvace, but negative for slow-growing larvae on "PI 227687". Larval growth rates were significantly $(P<0.05)$ and positively associated with ECI and ECD for the slow-growing larvace, but the corrclations were not significant for the fast-growing larvae. AD) was negatively associated with I:(iI and $\mathrm{ECD}$ for the fast-growing larvac, but positively associated for the slow-growing larvac (except for AD versus ECD on "Davis").

Table 3. Correlation matrix between various indices of consumption and utilization of food for the fast- and slow-growing larvae of cabbage looper on 'PI 227 687' and 'Davis' soybeans

\begin{tabular}{|c|c|c|c|c|}
\hline & \multicolumn{2}{|c|}{ 'P| 227687 ' } & \multicolumn{2}{|c|}{ 'I Davis' } \\
\hline & liast growing & Slow growing & Fast-growing & Slow-growing \\
\hline $\mathrm{Cl}: \mathrm{GK}$ & $-0.35 * \%$ & $-0.97^{m+n}$ & 0.13 & $0.64^{\prime \prime}$ \\
\hline $\mathrm{CI}: \mathrm{ECI}$ & $-0.92^{m *}$ & $-0.99^{m+k}$ & $-0.85^{m *}$ & 0.35 \\
\hline $\mathrm{Cl}: \mathrm{AI})$ & $0.81^{*+4}$ & $-0.78 \cdots$ & $0.72^{\prime \prime}$ & 0.32 \\
\hline CI:ECD & $-0.91+* 2$ & $-0.94^{m}$ & $-0.79^{\prime \prime \prime 3 ~}$ & 0.27 \\
\hline GR:ECl & 0.53 & $0.98^{m+4}$ & 0.41 & $0.94^{x+\pi}$ \\
\hline GR:ECD & 0.42 & $0.99 m$ & 0.44 & $0.86^{* 4 *}$ \\
\hline GR:AD & 0.09 & 0.61 & 0.04 & 0.34 \\
\hline ECI:AD & $-0.79^{m p}$ & 0.76 m & -0.67 & 0.35 \\
\hline ECI:ECD & $0.99^{n+1 *}$ & $0.95^{n}$ & $0.96 \%$ & $0.91^{\prime \prime}$ \\
\hline AD:ECD & $-0.86^{\text {*n }}$ & 0.52 & $-0.80^{\text {ntr }}$ & -0.02 \\
\hline \multicolumn{5}{|c|}{$\begin{array}{l}\text { * Significant at } P<0.05 \text { and } P<0.01 \text {, respectively. } C I=\text { Consumption index, GR }=\text { Growth } \\
\text { rate, } E C I=\text { Efficiency of conversion of ingested food into body matter, } A D=\text { Approximate } \\
\text { digestibility, and } E C D=\text { Efficiency of conversion of digested food into body matter. }\end{array}$} \\
\hline
\end{tabular}




\section{Discussion}

The overall performance of insects is dependent on size, which in turn is correlated with pupal mass (Kester and Smith 1984; Slansky and SCriber 1985). Pupal mass is dependent on the larval maximum mass that a larva attains in the final instar. The later is dependent on the quality of nutrition, and amount of food eaten during the latent feeding period (period between achieving a critical mass in the first instar and the maximum larval mass in the final instar) (OCHIENG-Odero 1990). Fast-growing and heavy individuals are superior to slowgrowing and light-individuals (OChIENG-Odero 1990). Slow-growing larvae of T.ni developed 10 times slower than the fast-growing larvae, and this can be attributed to their innate differences in consumption and utilization of food.

Ingestion of food/unit of larval mass (consumption index, $\mathrm{CI}$ ) was significantly lower for the slow-growing larvae, and these differences were greater on the insect-resistant cultivar, "PI 227687" than on the susceptible cultivar, "Davis". Slow-growing larvae were also significantly less efficient in conversion of ingested (ECI) and digested (ECD) food into body matter, and in approximate digestibility (AD). However, the differences in ECD were more pronounced on "PI 227687" than on "Davis", suggesting that slow-growing larvae were also more sensitive to the antifeedant and/or antibiotic effects of isoflavonoids present in "PI 227687" (Sharma and Norris 1991).

Thus, fast-growing larvae were more efficient in utilizing the relatively-resistant cultivar, "PI 227687". In addition to having a rapid generation turn over, the fast-growing larvae in $T$. ni populations represent an evolution of individuals having a greater adaptation to the environment including their capability of utilizing host-plants resistant to insects. Increase in the proportion of fast-growing individuals capable of utilizing diverse sources of food or crop cultivars resistant to insects is one of the mechanisms by which the phytophagous insects may overcome plant resistance, and lead to the evolution of new biotypes. The slow-growing T. ni larvae are less efficient in consumption and utilization of food, and they were more sensitive to cultivars resistant to insects.

\section{Acknowledgements}

This research was supported by the College of Agricultural and Life Sciences, University of Wisconsin, Madison; and in part by funds from U.S. Hatch Project No. 2786, and 3040, CRGO/ USDA Research Grant No. 84-CRCR-1-1501 and No. 88-37153-4043 and the University of Wisconsin A. I. D. Title XII strengthening grant. Approved as J. A. No. 1186 by ICRISAT.

\section{Zusammenfassung}

Unterschiedc in Nabrungsaufnabme und -verwertung bei langsam-und schnellwachsenden Larven von Trichoplusia ni (Hübner) (Lep., Noctuidae)

Unter Laborbedingungen wurde die Aufnahme und Verwertung von Sojabohnenblättern durch schnell und langsam wachsende Larven von Trichoplusia ni untersucht. Schnellwachsende Larven nahmen in bezug auf ihre Körpermasse mehr Nahrung auf und erreichten eine 10mal raschere Gewichtszunahme als langsamwachsende Larven. Bei langsamwachsenden Larven war eine geringere Effizienz der Nahrungsverwertung festzustellen. Diese Unterschiede in der Nahrungsverwertung waren auf der vergleichsweise resistenten Sojabohnensorte "PI 227687“ größer als auf der empfindlichen Sorte "Davis“. Die Ergebnisse werden im Hinblick auf die Züchtung neuer Biotypen von resistenten Wirtspflanzen diskutiert.

\section{References}

Broadley, H. K.; SAUnders, D. S., 1986: The relationship between early and late pupariation in the flesh-fly, Sarcophaga argyrostoma, and its effect on the incidence of pupal diapause. Physiol. Entomol. 1, 371-382.

Fehr, W. R.; Caviness, C. E.; Burmood, D. T.; Pennington, J. S., 1971: Stage of development descriptions for soybeans, Glycine max (L.) Merill. Crop Sci. 11, 929-931. 
Kester, K. M.; SMITH, C. M., 1984: Effects of diet on growth, fecundity and duration of tethered flight of Nezara viridula. Entomol. exp. appl. 35, 75-81.

OChiEng-Odero, J. P. R., 1990: Selection for rate of development and pupal weight in Conephasis jactatana: A genetic tool for quality improvement. Entomol. exp. appl. 54, 1-8.

PrICE, P. W: 1984: Insect ecology. New York: John Wiley and Sons.

Sharma, H. C.; Norris, D. M., 1991: Chemical basis of resistance in sovbean to cabbage looper, Trichoplusia ni. J. Sci. Fd. Agric. 55, 353-364.

Shorey, H. H.; Hale, R. L., 1965: Mass rearing of the larvae of nine noctuid species on a simple artificial medium. J. Econ. Entomol. 58, 522-524.

Slansky, F. Jr; SCRIBER, J. M., 1985: Food consumption and utilization. In: Comprehensive insect physiology, biochemistry and pharmacology. Vol. Il. Ed. by G. A. Kerkut: l. I. Gil.bert. Oxford, U. K.: Pergamon Press, pp. 87-163.

Smi.oritz, W.; SMith, C. L., 1970: Distributions and frequencies of weight of cabbage looper larvac reared on artificial diet. J. Econ. Fntomol. 63, 1106-1107.

TignoR, K. R.; EATON, J. L., 1986: Effects of prolonged colonization, crowding, and starvation on development and survival rates of cabbage looper. Trichoplusis $n i$ (Hübner) (Lepidoptera: Noctuidae). J. Entomol. Sci. 21, 68-82.

Wai.dbauer, G. P., 1968: Consumption and utilization of food by insects. Adv. Insect Physiol. 5, 229-288.

Authors' addresses: H. C. Sharma (for correspondence), Cereals Entomology, International Crops Research Institute for Semi-Arid Tropics (ICRISAT), Patancheru, A. P. 502324, India; D. M. NorkIs, Department of Entomology, 237 Russel Labs., University of Wisconsin, Madison, Wisconsin 5.3706, USA 